\title{
ANALISIS PENGARUH FAKTOR DETERMINAN TERHADAP ECONOMIC VALUE ADDED DAN IMPLIKASINYA TERHADAP PERGERAKAN HARGA SAHAM PROPERTI DI BURSA EFEK INDONESIA
}

\author{
Afriyeni, Jhon Fernos \\ Akademi Keuangan dan Perbankan Padang \\ afriyeni@akbpstie.ac.id
}

\begin{abstract}
Property sector companies whose shares are traded on the Indonesia Stock Exchange (IDX) has a period of booming growth dynamics of a property crash period when the economic crisis. Economic Value Added (EVA) valuing the company economically while assessing the company's stock price is the market. Four determinant factors in the EVA model framework: profitability (ROA), capital structure (debt ratio), beta stocks and interest rates; investigated its effect on EVA and its implications for stock price movement. Testing hypotheses through stages: (i) the design of the model-path (path analytical model), (ii) parameter estimation, (iii) analysis of the model, and (iv) model evaluation. Estimation models with SPSS ver ver 10:05 and 8:51 LISREL. The results are: (i) EVA influenced by, from the most dominant, ROA profitability levels, interest rates, debt ratio, and beta stocks $(R 2=95 \%)$. ROA has a positive effect, interest rate and debt ratio negatively, whereas no significant effect of beta stocks (balance); (ii) The movement of stock prices are influenced by, from the most dominant, beta stocks, interest rates, ROA, and the debt ratio $(R 2=20 \%)$. ROA beta and positive influence, a negative influence interest rates, whereas the effect of debt ratio balance; (iii) If the ROA rose one standard unit, precision EVA rose 0.98 units and the stock price rose 0.20 units, if the interest rates go down one unit, EVA rose by 0.10 , the stock price rose 0.25 units; if debt ratio down one unit, EVA rose 0.06 units, but does not cause a change in the stock price; when beta stocks rose one-unit standard, EVA has not changed but the stock price will rise by 0:37 units, ceteris paribus. Single regression analysis model EVA exogenous to the movement of stock prices show that the company's share price movements in the property sector IDX very little influenced by variations in EVA (4.7\%), the stock price will rise by 0:22 dipresisikan if EVA unit up one unit, ceteris paribus.
\end{abstract}

Keywords: real estate, EVA, ROA, debt ratio, beta stocks, interest rates, movements stock prices, regression, path analysis.

\section{PENDAHULUAN}

Perusahaan sektor industri properti pada umumnya adalah perusahaanperusahaan besar dengan kegiatan utamanya menyediakan produk perumahan, real estate, perkantoran, kondominium, area rekreasi massa, dan sebagainya. Perusahaanperusahaan ini memperdagangkan sahamnya di Bursa Efek Indonesia dengan tujuan memaksimalkan nilai perusahaan. Salah satu pendekatan dalam menentukan nilai ekonomi perusahaan adalah pendekatan Economic Value Added (EVA). EVA mengevaluasi nilai ekonomi perusahaan dengan menentukan selisih antara tingkat 
profitabilitas perusahaan secara akuntansi dengan tingkat profitabilitas minimal yang diharapkan investor. Seberapa besar selisih tersebut merupakan nilai tambah (value added) profitabilitas bagi investor (Scott, et.al, 1999, hal. 112-113).

Perekonomian Indonesia sebelum periode krisis ekonomi tahun 1997-1999 menunjukan performa yang baik (Tabel 1). Keadaan ini sangat kondusif bagi iklim investasi dalam berbagai sektor, termasuk sektor industri properti. Bagi perusahaan sektor properti, periode tahun 1990 sampai tahun 1996 (periode sebelum krisis eknomi) merupakan periode booming dengan semaraknya pembangunan kawasan perumahan, hunian mewah, kondominium, komplek perkantoran, kawasan wisata, agrowisata, dan resort terpadu. Namun pada periode krisis ekonomi, perusahaan sektor properti mulai lesu dan akhirnya terjadi property crash tahun 1998, hampir seluruh perusahaan sektor ini mengalami kerugian.

Tabel 1.

Kondisi Ekonomi Makro dan Sektor Properti 1995 - 2004

\begin{tabular}{|l|rrrr|l|}
\hline Ekonomi: & $\begin{array}{r}\text { Growth } \\
(\%)\end{array}$ & $\begin{array}{r}\text { Inflasi } \\
(\%)\end{array}$ & Rp./USD & $\begin{array}{r}\text { SB } \\
(\%)\end{array}$ & $\begin{array}{c}\text { Sektor } \\
\text { Properti }\end{array}$ \\
\hline Sebelum krisis (95-97) & 8.1 & 1.9 & 2,300 & 12.7 & $\begin{array}{l}\text { Booming } \\
\text { Property }\end{array}$ \\
& & & & & \\
Periode krisis (98-99) & -2.3 & 21.2 & 6,878 & 34.1 & Crash \\
Setelah krisis (00-04) & 4.1 & 8.0 & 9,124 & 12.3 & $?$ \\
\hline
\end{tabular}

Sumber : diolah dari Publikasi Bank Indonesia, www.bi.go.id

Keadaan makro ekonomi nasional pada periode krisis ekonomi (1998-1999) sangat buruk. Keadaan ini membawa dampak terutama pada penurunan daya beli masyarakat dan naiknya biaya pinjaman, sehingga tidak lagi kondusif bagi iklim investasi nasional khususnya iklim investasi dalam sektor industri properti.

Perekonomian nasional periode 2000-2004, pasca periode krisis ekonomi, kondisinya semakin membaik. Naiknya pertumbuhan ekonomi dan turunnya tingkat suku bunga berdampak terhadap pulihnya daya beli masyarakat dan kinerja usaha industri termasuk industri sektor properti. Hal ini menunjang menguatnya kinerja keuangan (fundamental) perusahaan dan pada akhirnya mendorong investor untuk berinvestasi pada saham sehingga meningkatkan kinerja saham-saham perusahaan sektor industri properti. Dengan demikian faktor kondisi makro ekonomi memicu kondisi kinerja fundamental dan kinerja saham, bagi perusahaan hal ini akan mempengaruhi nilai profitabilitas perusahaanya secara ekonomi (EVA).

Faktor-faktor kinerja fundamental, kinerja saham, dan kondisi makro ekonomi dalam kerangka teoritik konsep EVA adalah tingkat profitabilitas (setelah pajak), struktur modal, beta saham dan tingkat suku bunga. Keempat faktor ini merupakan faktor-faktor determinan EVA. EVA menilai perusahaan secara ekonomi sedangkan harga saham menilai perusahaan dari aspek pasar. Jika penilaian secara ekonomi selaras dengan penilaian pasar, maka terjadinya perbedaan dalam EVA setara dengan terjadinya perbedaan dalam pergerakan harga saham. Dengan perkataan lain, perbedaan dalam EVA akan menyebabkan perbedaan dalam pergerakan harga saham. Oleh karena EVA ditentukan oleh faktor-faktor determinannya, dan jika perbedaan dalam EVA menyebabkan perbedaan dalam pergerakan harga saham, maka perbedaan dalam faktor-faktor determinan selain akan menyebabkan perbedaan dalam EVA juga akan menyebabkan perbedaan dalam pergerakan harga saham. Bagaimanakah pengaruh profitabilitas, struktur modal, beta saham dan tingkat suku bunga terhadap EVA serta bagaimana implikasinya terhadap pergerakan harga saham perusahaan sektor properti di BEI? 
Model hubungan EVA dan faktor-faktornya dengan pergerakan harga saham perlu dibangun untuk memperoleh kajian empiris pada perusahaan-perusahaan sektor properti di BEI mengenai pengaruh faktor-faktor determinan terhadap EVA dan implikasinya terhadap pergerakan harga sahamnya, yaitu: (i) mengetahui keselarasan kondisi EVA dengan pergerakan harga saham perusahaan sektor properti di BEI, (ii) menyusun model hubungan antara faktor-faktor determinan dengan EVA pada perusahaan sektor properti di BEI, dan (iii) menyusun model hubungan antara faktorfaktor determinan EVA dengan pergerakan harga saham pada perusahaan sektor properti di BEI.

\section{METODE PENELITIAN}

\section{Model Economic Value Added}

Economic Value Added (EVA) suatu perusahaan adalah laba operasi setelah pajak dikoreksi dengan biaya modal dari total nilai investasinya dalam suatu periode tertentu (misalnya bulanan, kwartalan, atau tahunan). EVA disebut juga economic profit karena EVA mengukur laba perusahaan secara ekonomi. EVA dirumuskan sebagai berikut (Scott, et.all. 1999, Ross, et.al. 2002, Bodie, et.al, 2002),

$$
\mathrm{EVA}=\mathrm{NOPAT}-k \mathrm{C}
$$

dimana

$$
\begin{aligned}
& \text { NOPAT } \\
& \begin{aligned}
& k \text { net operating profit after taxes, laba bersih setelah pajak } \\
& \text { = cost of capital, biaya modal } \\
& \mathrm{C}=\text { invested capital }, \text { modal terinvestasi. }
\end{aligned}
\end{aligned}
$$

dimana

$$
k=w_{D} k_{D}\left(1-T_{C}\right)+w_{E} k_{E}
$$

$$
\begin{array}{ll}
=\text { biaya pinjaman }(\text { cost of debt }) \\
k_{E} & =\text { biaya saham }(\text { cost of ekuity }) \\
w_{D} & =\text { proporsi pinjaman } \\
w_{E} & =\text { proporsi saham, } w_{E}=\left(1-w_{D}\right) \\
T_{C} & =\text { tingkat pajak }
\end{array}
$$

Biaya pinjaman, $k_{D}$, dalam prakteknya dianggap setara dengan tingkat suku bunga pinjaman (kredit). Sedangkan biaya saham, $k_{E}$, setara dengan tingkat keuntungan yang diharapkan oleh investor. Besar biaya saham, $k_{E}$, dihitung melalui metode Capital Aset Pricing Model (CAPM), sebagai

$$
k_{E}=k_{r f}+\beta\left(k_{M}-k_{r f}\right)
$$

dimana: $k_{E}=$ tingkat keuntungan investasi saham yang diharapkan oleh investor

$k_{r f}=$ tingkat keuntungan aset tanpa resiko (risk free rate)

$\beta=$ resiko sistematik suatu saham relatif terhadap resiko portofolio pasar

$k_{M}=$ tingkat harapan keuntungan investasi portofolio pasar

Persamaan [1], [2] dan [3] menunjukkan bahwa secara teoritis EVA adalah kinerja faktor fundamental yang disesuaikan dengan kondisi makro ekonomi dan kinerja saham. Faktor fundamental secara eksplisit ditunjukkan oleh profitabilitas setelah pajak (NOPAT) dan struktur modal (debt ratio). Sedangkan faktor makro ekonomi dan kinerja saham masing-masing ditunjukkan oleh tingkat suku bunga dan koefisien beta saham. Jadi kondisi EVA bergantung kondisi empat faktor determinan yaitu profitabilitas, struktur modal, tingkat suku bunga dan beta saham.

Nilai total modal investasi $\mathrm{C}$ diperoleh dengan cara mengurangi total aktiva (total asset) dengan hutang lancar tak berbunga (Non Interested Bearing Current Liabilities, NIBCL). NIBCL merupakan hutang-hutang lancar untuk hutang usaha, hutang pajak, biaya yang masih harus dibayar, uang muka pelanggan, dan hutang lancar lainnya yang tidak dikenakan bunga (Young and O'Byrne, 2001). 


\section{Profitabilitas dan Struktur Modal}

Perspektif akuntansi mengevaluasi fundamental keuangan perusahaan dengan cara menganalisis rasio-rasio keuangan dari laporan keuangan yang terbit dengan mengikuti kaidah-kaidah tertentu (akuntansi). Rasio-rasio keuangan dapat dikelompokan kedalam indikator-indikator yang terdiri atas : rasio liquiditas, rasio aktivitas, rasio leverage (debt ratio), rasio profitabilitas, dan rasio capital value (Ross, et.al, 2002). Rasio-rasio indikator kinerja keuangan yang berhubungan langsung dengan konsep teoritis EVA adalah struktur modal dan profitabilitas. Struktur modal adalah rasio yang menggambarkan struktur permodalan. Struktur modal merupakan strategi perusahaan dalam mendanai operasi dan aset perusahaan melalui pinjaman, biasanya diukur oleh debt ratio yaitu rasio antara total pinjaman terhadap total aset. Rasio profitabilitas adalah rasio yang menggambarkan kemampuan perusahaan dalam menghasilkan laba dari aset yang dimilikinya, diukur dengan ROA (Return on Asset) yaitu rasio antara laba bersih setelah pajak terhadap total aset.

\section{Pergerakan Harga Saham dan Koefisien Beta}

Penilaian kinerja saham perusahaan dari luar perusahaan dilakukan oleh pasar melalui pola perilaku pergerakan harga saham dari waktu ke waktu. Harga saham (market price) merupakan nilai pasar (market value) dari setiap lembar saham perusahaan. Pergerakan harga saham ditentukan oleh dinamika penawaran (supply) dan permintaan (demand). Pada suatu periode tertentu, penawaran suatu saham adalah tetap sehingga kurvanya vertikal pada angka tertentu. Permintaan pasar (market demand) merupakan permintaan agregat dari seluruh investor, sehingga kurvanya relatif horizontal. Keseimbangan harga terjadi saat kurva penawaran dan permintaan agregat berpotongan pada suatu titik. Karena kurva penawaran bersifat tetap maka pergerakan harga saham diakibatkan oleh pergerakan (pergeseran) kurva permintaan. Apabila kurva permintaan naik, maka kesimbangan baru terjadi pada harga yang lebih tinggi (harga naik), dan apabila permintaan turun, maka harga turun. Jadi perilaku harga suatu saham merupakan cermin permintaan agregat dari para investor.

Oleh karena pergerakan harga saham disebabkan oleh pergerakan kurva demand, maka faktor-faktor penggerak demand menjadi faktor-faktor yang mempengaruhi perubahan harga saham. Berdasarkan hipotesis pasar berlaku efisien (eficient market hypothesis), semua informasi yang relevan berpengaruh terhadap harga saham, termasuk diantaranya adalah kinerja fundamental, kinerja saham selama ini, dan kondisi makro ekonomi (Bodie, Kane dan Marcus, 2002). Dengan demikian, EVA dan keempat faktor determinannya juga merupakan faktor-faktor penggerak demand saham yang akan berpengaruh terhadap pergerakan harga saham.

Perbandingan pergerakan harga suatu saham relative terhadap pergerakan seluruh saham dalam portfolio pasar merupakan ukuran bahwa pergerakan saham tersebut mengikuti pergerakan harga saham-saham lainnya. Besar tingkat keterkaitan pergerakan harga suatu saham dengan seluruh saham dalam portfolio pasar diukur dengan suatu indeks atau koefisien yang disebut Beta saham.

Investor dalam membentuk portofolio aset-aset investasinya akan mempertimbangkan resiko dan tingkat keuntungan. Apabila seorang investor membentuk suatu portofolio maka investor akan mendapat keuntungan sebesar ratarata terbobot dari masing-masing tingkat keuntungan aset, dengan resiko portofolio yang lebih kecil dari resiko terbobot dari masing-masing resiko aset. Besarnya tingkat keuntungan dan resiko portofolio tergantung dari jumlah aset yang membentuk portofolio tersebut. Resiko portofolio tergantung dari korelasi tingkat keuntungan antar aset, sedangkan rata-rata tingkat keuntungan portofolio tidak tergantung dari korelasi tingkat keuntungan antar aset. Sifat portofolio ini menguntungkan bagi 
investor karena investor dapat melakukan diversifikasi untuk mengurangi resiko portofolionya (Bodie, et.al. 2002, hal 211).

Seluruh aset saham yang diperdagangkan di suatu pasar saham akan membentuk portofolio keseluruhan saham yang disebut portofolio pasar. Proporsi setiap saham dalam portofolio pasar sama dengan nilai pasar saham tersebut (harga dikali jumlah saham yang beredar) dibagi dengan jumlah nilai pasar seluruh saham. Portofolio pasar merupakan portofolio yang optimal karena di-diversifikasi secara efisien dari cakupan seluruh saham. Rata-rata tingkat keuntungan, $k_{M}$, dan resiko portofolio pasar, $\sigma_{M}$, adalah

$$
k_{M}=\sum_{i=1}^{N} w_{i} k_{i} \quad[4], \quad \sigma_{M}=\left[\sum_{j=1}^{N} \sum_{i=1}^{N} w_{i} w_{j} \operatorname{Cov}\left(k_{i}, k_{j}\right)\right]^{1 / 2}
$$

dimana $w_{i}, k_{i}$, dan $\operatorname{Cov}\left(k_{i}, k_{j}\right)$ masing-masing adalah proporsi saham $i$, tingkat keuntungan saham $i$, dan kovariansi saham $i$ dengan saham $j$ (Bodie, et.al. 2002, hal. 249; 269). Resiko portofolio pasar disebut juga resiko pasar (market risk) atau resiko sistematik. Pada persamaan [5] jika $i=j$ maka $\operatorname{Cov}\left(k_{i}, k_{j}\right)=\operatorname{Cov}\left(k_{i}, k_{i}\right)=\sigma_{i}^{2}$, variansi suatu saham, dan $\sigma_{i}$ adalah resiko saham tersebut, yaitu standar deviasi dari variansi saham.

Dalam kesimbangan rata-rata tingkat keuntungan aset saham, diasumsikan bahwa semua investor adalah rasional (mempertimbangkan optimalisasi tingkat keuntungan-resiko) dan melakukan analisis dengan cara yang sama dalam menentukan portofolio yang optimal. Implikasinya adalah semua investor akan membentuk portofolio yang memiliki karakteristik sama dengan karakteristik portofolio pasar. Misalnya proporsi aset-aset dalam portofolio yang akan dibentuk investor meniru proporsi aset-aset dalam portofolio pasar. Implikasi lainnya adalah bahwa resiko premium (risk premium) pada individu aset akan proporsional terhadap resiko premium pada portofolio pasar. Faktor tingkat proporsi tersebut adalah koefisien beta untuk saham tersebut. Beta saham didefinisikan sebagai

$\beta_{i}=\frac{\operatorname{Cov}\left(k_{i}, k_{M}\right)}{\sigma_{M}^{2}} \quad[6]$, dimana $\operatorname{Cov}\left(k_{i}, k_{M}\right)=\sum_{j=1}^{N} w_{j} \operatorname{Cov}\left(k_{i}, k_{j}\right)$, adalah rata-rata terbobot kovariansi keuntungan suatu saham $i$ dengan saham lainnya dalam portofolio pasar (Bodie, et.al, 2002, hal.265; Ross, et.al, 2002, hal. 271).

Interpretasi koefisien beta saham adalah sebagai berikut. Pertama, mengukur tingkat respon pergerakan keuntungan suatu saham berdasarkan pergerakan keuntungan (portofolio) pasar. Kedua, mengukur tingkat resiko sistematik suatu saham terhadap resiko sitematik pasar. Estimasi nilai koefisien beta saham dilakukan secara empirik dengan mengamati pertumbuhan indeks harga saham gabungan dan indeks harga saham tersebut (Ross, et.al, 2002, hal. 310). Variansi-kovariansi dari indeks harga saham gabungan dan indeks harga suatu saham masing-masing dapat dihitung, sehingga dengan menggunakan persamaan [6] koefisien beta saham dapat diperoleh.

Investor menggunakan informasi beta untuk membentuk portofolio investasi. Koefisien beta dari kombinasi aset-aset dalam suatu portofolio sama dengan rata-rata terbobot dari masing-masing beta, dan untuk koefisien beta portofolio pasar rata-rata terbobot tersebut sama dengan satu. Jadi untuk portofolio yang besar (melibatkan banyak aset) maka koefisien beta portofolio akan mendekati nilai satu. Jika suatu portofolio memiliki koefisien beta sama dengan satu, maka investasi pada portolio tersebut telah mempunyai efisiensi diversifikasi dari pada berinvestasi hanya pada suatu saham yang memiliki koefisien beta sama dengan satu. Akan tetapi tingkat 
efisiensi diversifikasi portofolio berkeofisien beta sama dengan satu ini tidak akan menyamai efisiensi diversifikasi portofolio pasar.

Oleh karena beta saham mempunyai karakteristik sebagai alat untuk mendiversifikasi resiko portofolio, maka hubungan beta saham dengan pergerakan harga saham tergantung langsung kepada keputusan investor. Artinya bahwa hubungan beta saham dengan pergerakan harga saham merupakan cermin perilaku/strategi investor dalam membentuk portofolio investasinya. Jika sebagian besar investor memilih saham dengan beta tinggi untuk membentuk portofolionya, maka kecenderungannya adalah harga saham tersebut naik karena naiknya permintaan. Sebaliknya jika investor lebih banyak yang memilih saham dengan beta rendah, maka kecenderungannya adalah harga saham tersebut juga naik karena naiknya permintaan saham-saham yang mempunyai beta rendah. Jadi, secara empiris, beta saham bisa berpengaruh positif atau negatif terhadap pergerakan harga saham.

Dalam kerangka model EVA dengan pendekatan CAPM, investor menggunakan nilai koefisien beta saham untuk menentukan tingkat keuntungan yang diharapkan atas suatu saham (biaya saham, $k_{E}$ pada persamaan [3]) yang merupakan salah satu komponen biaya modal. Menurut persamaan [3], jika nilai beta besar maka biaya saham juga besar. Dan jika mengikuti persamaan [2] sdan [1] maka pada akhirnya akan membuat EVA kecil. Jadi secara teoritis beta saham berpengaruh negatif terhadap EVA.

Beta saham yang merupakan ukuran tingkat keuntungan yang diharapkan dari suatu saham juga akan digunakan oleh investor untuk menilai harga wajar (fair prices) dari saham tersebut. Dengan menggunakan model deviden discount factor, beta saham (tingkat keuntungan yang diharapkan dari saham) yang tinggi akan menyebabkan harga wajarnya rendah, sehingga saham tersebut cenderung overvalued, selanjutnya investor menganggap opsi yang paling menguntungkan dari keadaan ini adalah melepas saham. Apabila saham-saham dengan beta tinggi (yang dianggap overvalued tadi) banyak dilepas ke pasar maka suply saham-saham tersebut akan naik yang akhirnya pergerakan harga sahamnya akan turun. Hal ini berarti dengan menggunakan pendekatan harga wajar, beta saham akan mempengaruhi secara negatif pergerakan harga saham.

\section{Tingkat Suku Bunga}

Informasi kondisi makro ekonomi diperlukan investor untuk melakukan investasi. Kondisi makro ekonomi secara keseluruhan akan mempengaruhi kegiatan ekonomi masyarakat, pengusaha dan investor. Kondisi makro ekonomi yang baik akan menciptakan iklim investasi yang baik.Beberapa variabel kondisi ekonomi nasional yang biasanya digunakan adalah tingkat pertumbuhan ekonomi, tingkat inflasi, tingkat suku bunga, dan nilai tukar rupiah (khususnya terhadap US Dollar). Dalam kerangka model EVA, kondisi makro ekonomi yang terkait langsung adalah tingkat suku bunga. Tingkat suku bunga merupakan ukuran keuntungan investasi yang dapat diperoleh oleh investor dan juga merupakan ukuran biaya modal yang harus dikeluarkan oleh perusahan untuk menggunakan dana dari investor.

Hubungan antara tingkat bunga dengan EVA adalah berlawanan. Apabila terjadi kenaikan tingkat suku bunga, maka pergerakan harga saham akan menurun, sebaliknya apabila terjadi penurunan tingkat suku bunga, maka harga saham akan naik (Bodie, et.al., 2002, hal. 539). Semakin tinggi tingkat bunga perbankan, akan menyebabkan investor mengalihkan investasinya pada investasi di perbankan, obligasi atau aset-aset keuangan berpendapatan tetap. Karena investor mengurangi portofolio saham dengan melepas saham, maka suplai saham di bursa saham meningkat dan selanjutnya akan menyebabkan penurunan harga saham tersebut. 
Penurunan harga saham yang terus menerus akan menaikan struktur leverage yang akan meningkatkan dominasi komposisinya dalam biaya modal sehingga EVA menurun.

\section{Hipotesis}

Model hubungan ROA, debt ratio (DR), beta saham (BT), tingkat suku bunga (SB), EVA dan pergerakan harga saham (PHS) digambarkan menggunakan diagram analisis jalur (path analysis) berdasarkan anggapan bahwa faktor kondisi ekonomi (SB) mempengaruhi kondisi fundamental (ROA, DR, EVA) dan kondisi pasar (BT, PHS), serta faktor fundamental mempengaruhi kondisi pasar.

Model yang dibangun terdiri atas hipotesis-hipotesis hubungan antar variabel sesuai skenario model EVA. Apabila proposisi hipotesis diposisikan sebagai hipotesis alternatif $\left(H_{a}\right)$, rumusan hipotesisnya selengkapnya sebagai berikut:

$H_{a 1}$ : ROA, debt ratio, beta saham dan suku bunga berpengaruh secara bersama-sama terhadap EVA

$H_{a 2}$ : ROA berpengaruh positif terhadap EVA

$H_{a 3}$ : Debt ratio berpengaruh negatif terhadap EVA

$H_{a 4}$ : Beta saham berpengaruh negatif terhadap EVA

$H_{a 5}$ : Suku bunga berpengaruh negatif terhadap EVA

$H_{a 6}$ : EVA, ROA, debt ratio, beta saham dan suku bunga berpengaruh secara bersama-sama terhadap pergerakan harga saham

$H_{a 7}$ : $\quad$ EVA berpengaruh positif terhadap pergerakan harga saham

$H_{a 8}$ : $\quad$ ROA berpengaruh positif terhadap pergerakan harga saham

$H_{a 9}$ : Debt ratio berpengaruh negatif terhadap pergerakan harga saham

$H_{a 10}$ : Beta saham berpengaruh negatif terhadap pergerakan harga saham

$H_{a 11}$ : Suku bunga berpengaruh negatif terhadap pergerakan harga saham.

\section{Rancangan Penelitian}

Penelitian bersifat causal analysis untuk menguji hipotesis-hipotesis pengaruh antar variabel. Rancangan penelitian ini terdiri dari empat tahap yaitu: (i) perancangan model, (ii) estimasi parameter, (iii) analisis model, dan (iv) evaluasi model.

Tahap pertama adalah perancangan kerangka model berdasarkan pengetahuan teori untuk dibandingkan terhadap penerapannya dalam kondisi empirik (data) tertentu. Misalnya, dalam penelitian ini, kondisi (setting) ekonomi, fundamental, dan kinerja saham diuji interelasinya terhadap tatanan empirik perusahaan-perusahaan sektor properti sebagai kondisi nyata yang terjadi Bursa Efek Indonesia (BEI). Jenis model analisis jalur (path analyitical model) dirancang untuk menerangkan interelasi EVA dan factor-faktornya terhadap pergerakan harga saham. Rancangan model harus dapat menjawab rumusan hipotesis terdahulu.

Tahap kedua adalah estimasi parameter dan validasinya. Parameter dinyatakan dalam koefisien regresi terstandardisasi (standardized regression coefficient) yang diturunkan dari estimasi persamaan regresi berganda menggunakan program SPSS 13.5 atau LISREL 8.51. Validasi model regresi diestimasi dengan SPSS maupun LISREL, dan validasi path model diestimasi dengan LISREL. Terdapat dua persamaan regresi utama yang akan dihasilkan dari model:

I. $\quad$ EVA $=f(R O A$, debt ratio, beta saham, suku bunga $)$

II. $\quad$ PHS $=\mathrm{f}(\mathrm{ROA}$, debt ratio, beta saham, suku bunga, EVA)

Tahap ketiga adalah analisis model yang meliputi analisis struktural dan analisis efek-ganda (multiplier). Analisis struktural meliputi signifikansi, besar dan arah pengaruh. Analisis multiplier merupakan analisis sensitivitas akan unit perubahan dalam variabel dependen (endogen) akibat perubahan yang terjadi dalam setiap unit variabel independen (eksogen). Misalnya berapa besar perubahan akan 
terjadi dalam EVA atau pergerakan harga saham jika satu atau lebih variable - ROA, debt ratio, beta saham, dan suku bunga - berubah satu unitnya.

Tahap keempat adalah evaluasi model dengan membandingkan hasil empirik dengan teori yang mendasarinya. Evaluasi ini terutama menyangkut arah koefisien pengaruh dari variabel-variabel dalam model.

\section{Data dan Variabel}

Pengumpulan data dilakukan dengan metode studi kepustakaan dan pengolahan data sekunder. Target populasi adalah perusahaan-perusahaan yang diperdagangkan di BEI yang termasuk ke dalam sektor properti; dan sebagai unit analisisnya adalah masing-masing perusahaan tersebut. Sampel data diambil selama lima tahun periode dari tahun 2000 sampai dengan 2004. Data dalam penelitian ini merupakan data sekunder, terdiri dari: $(i)$ data transaksi saham, meliputi: harga penutupan saham dan indeks harga saham gabungan (IHSG); (ii) data rasio keuangan, meliputi: data laporan rugi/laba dan neraca; (iii) data tingkat suku bunga meliputi suku bunga Sertifikat Bank Indonesia (SBI) dan Suku Bunga Kredit (SBK); dan (iv) data tingkat pajak. Seluruh data ini bersumber dari publikasi yang dilakukan masingmasing oleh BEI dan Bank Indonesia.

Data sekunder dalam penelitian diolah untuk mendapatkan variabel-variabel yang diperlukan dalam pengujian hipotesis penelitian. Tahap pengolahan data untuk menghasilkan variabel-variabel sesuai hipotesis adalah sebagai berikut: (i) Memuat grafik pergerakan harga saham harian dan menghitung rata-rata pergerakan (slope) harga saham sepanjang tahun dengan metode regresi; (ii) membuat indeks pertumbuhan harga saham dan IHSG, kemudian menghitung/mengestimasi koefisien Beta saham dengan formula [6]; (iii) menghitung NOPAT, ROA, DR, NIBCL dan nilai modal (invested capital) dari Laporan Keuangan Tahunan; (iv) menghitung biaya pinjaman, biaya saham, dan biaya modal terbobot (average weighted cost of capital) dengan formula [2] dan [3]; dan, (v) menghitung EVA dengan formula [1]. Pemodelan dalam penelitian ini menggunakan record data yang bersesuaian dengan pergerakan harga saham (slope) yang dikategorikan menaik atau menurun.

\section{Metode Analisis Data}

Pengujian hipotesis dalam penelitian ini akan dilakukan melalui analisis data secara statistic, analisis regresi dan analisis jalur. Analisis regresi berganda digunakan untuk membuat model hubungan langsung. Analisis ini memerlukan asumsi bahwa variabel prediktor adalah variabel yang dapat dikontrol (non rondom variabel) dan tidak saling berkorelasi, variabel galat (error term) berdistribusi normal dengan rataan nol dan variansi homogen. Validasi model ini diukur dengan koefisien determinasi $\left(R^{2}\right.$ ) yang bernilai antara 0 sampai 1 . Signifikasi model dan parameter pengujian hipotesis secara statistik ditentukan oleh statistik uji $F$ dan uji $t$ (Ryan, 1997).

Analisis jalur (path analysis) digunakan untuk mempelajari sistem pengaruh beberapa variabel terhadap beberapa variabel lain dalam suatu model berdasarkan kerangka teori tertententu. Jika hubungan variabel $\mathrm{X}$ dan $\mathrm{Y}$ hanya hubungan korelasi, maka digambarkan dengan lintasan panah melengkung dua arah, dan notasi ukuran hubungannya adalah korelasinya, $r_{X Y}$. Jika $\mathrm{X}$ mempengaruhi $\mathrm{Y}$ secara langsung digambarkan dengan lintasan panah lurus satu arah, notasi intensitas hubungannya disebut koefisien path, $p_{Y X}$. Definisi-definisi konsep dalam analisis jalur sebagai berikut (Pedhazur, 1982; hal. 178-181, hal.580-585) :

a. Variabel eksogen (exogenous) : adalah variabel yang mempengaruhi, disebut juga variabel independen. Variabilitas variabel ini hanya ditentukan oleh faktorfaktor di luar causal-model yang diteliti. 
b. Variabel endogen (endogenus) : adalah variabel yang dipengaruhi, disebut juga variable dependen. Variabilitas variabel ini ditentukan oleh variabel eksogen dan variabel endogen lainnya dalam causal-model yang diteliti.

c. Variabel intermediate (intervening) : adalah variabel antara yang dapat berfungsi sebagai variabel endogen atau variabel eksogen.

d. Pengaruh langsung (direct effect) : adalah bagian pengaruh suatu variabel eksogen terhadap variabel endogen tanpa perantaraan variabel lain.

e. Pengaruh tidak langsung (indirect effect) : adalah bagian pengaruh suatu variabel eksogen terhadap variabel endogen melalui variabel lain.

f. Pengaruh keseluruhan (total effect) : adalah jumlah pengaruh langsung dan semua pengaruh tidak langsung suatu variabel eksogen terhadap suatu variabel endogen.

g. Koefisien path : adalah ukuran intensitas pengaruh suatu variable eksogen terhadap variabel endogen. Koefisien path dilambangkan dengan $p$ merupakan koefisien regresi z-score (standardized regression coeficient).

h. Galat (error term), $\boldsymbol{\epsilon}$ : adalah komponen acak (unspecified) dari variabel endogen. Satu unit perubahan dalam galat akan menyebabkan $\left(1-R^{2}\right)^{1 / 2}$ perubahan dalam variabel endogen.

Asumsi dalam analisis jalur adalah sebagai berikut: $(i)$ hubungan diantara variabel dalam model adalah linier, aditif, dan bersifat causal; (ii) setiap komponen galat tidak berkorelasi dengan variabel endogen yang bersesuaian maupun dengan variabel-variabel dibawah endogen tersebut; (iii) hanya terdapat lintasan lurus satu arah dalam sistem (model rekursive), tidak ada pengaruh langsung yang bolak-balik (reciprocal); (iv) variabel diukur dalam skala sekurang-kurang pada skala interval; dan $(v)$ variabel diukur tanpa kesalahan pengukuran.

\section{HASIL DAN PEMBAHASAN}

\section{Model Analisis Jalur Faktor Determinan-EVA-PHS}

Korelasi antar variable dalam model dapat dilihat pada Tabel 2. terlihat bahwa antar faktor determinan ada korelasi yang cukup kuat, yaitu korelasi antara ROA dengan beta saham (0.23) dan EVA (0.97), antara beta saham dengan suku bunga (0.46), EVA (0.25) dan PHS (0.43), antara suku bunga dengan PHS (-0.24) dan korelasi antara antara EVA dengan PHS (0.22).

Tabel 2.

Matriks Korelasi Antar Variabel

\begin{tabular}{|l|c|c|c|c|c|c||}
\hline Variabel & ROA & DR & BT & SB & EVA & PHS \\
\hline ROA & 1 & -0.110 & $0.225^{*}$ & 0.008 & $0.971^{* *}$ & 0.191 \\
\hline DR & & 1 & -0.068 & 0.080 & -0.065 & -0.020 \\
\hline BT & & & 1 & $-0.458^{* *}$ & $0.254^{* *}$ & $0.429^{* * *}$ \\
\hline SB & & & & 1 & 0.087 & $-0.242^{*}$ \\
\hline EVA & & & & & 1 & $0.216^{*}$ \\
\hline PHS & & & & & & 1 \\
\hline
\end{tabular}

Correlation is significant (2-tailed) at the: 0.05 level $(*), 0.01$ level $(* *) . N=106$.

Berdasarkan anggapan bahwa faktor kondisi ekonomi mempengaruhi kondisi fundamental dan kondisi pasar, serta faktor fundamental mempengaruhi kondisi pasar, maka model yang dibangun adalah seperti pada Gambar 1. Model dibangun atas dua faktor determinan (SB dab DR) sebagai eksogen dan empat variabel endogen. Dari empat variabel endogen, tiga diantaranya juga berperan sebagai variabel perantara (intermediate) yaitu ROA, Beta Saham dan EVA. 
Model pada Gambar 1 terdiri atas empat persamaan regresi (standardized regression) yaitu persamaan [7] sampai dengan persamaan [10] yang telah lengkap dengan koefisien dari setiap jalurnya.

$$
\begin{array}{llrl}
\text { ROA } & =-0.11 \mathrm{DR} & , \epsilon^{2}=0.99 & {[7]} \\
\mathrm{BT} & =0.23 \mathrm{ROA}-0.46 \mathrm{SB} & , \epsilon^{2}=0.74 & {[\mathbf{8}]} \\
\mathrm{EVA} & =0.98 \mathrm{ROA}+0.05 \mathrm{DR}-0.01 \mathrm{BT}-0.10 \mathrm{SB} & , \epsilon^{2}=0.05 & {[\mathbf{9}]} \\
\text { PHS }=-0.10 \mathrm{ROA}+0.01 \mathrm{DR}+0.37 \mathrm{BT}-0.05 \mathrm{SB}+0.22 \mathrm{EVA} & , \epsilon^{2}=0.80 & {[\mathbf{1 0}}
\end{array}
$$

Model analisis jalur pada Gambar 1 merupakan model dengan dua derajat bebas, yaitu ada dua jalur yang mungkin dibuat dalam model tetapi dua jalur ini tidak dianalisis (overidentified) karena korelasinya yang sangat kecil. Kedua jalur tersebut adalah jalur $\mathrm{SB} \rightarrow \mathrm{ROA}$ dan jalur $\mathrm{DR} \rightarrow \mathrm{BT}$. Meskipun ada dua jalur yang tidak dianalisis, secara statistik model analisis jalur dengan derajat bebas dua ini valid, terlihat dari nilai uji kesesuaian khi-kuadrat yang kecil (p-value yang besar). Validitas model juga ditunjukkan oleh nilai RMSEA (Root Mean Square Error Approximation) yang nilainya sangat kecil mendekati nol. Validitas model ini menunjukkan bahwa jalur-jalur dan koefisien pengaruh dalam model secara struktural sesuai dengan data (model fits the data).

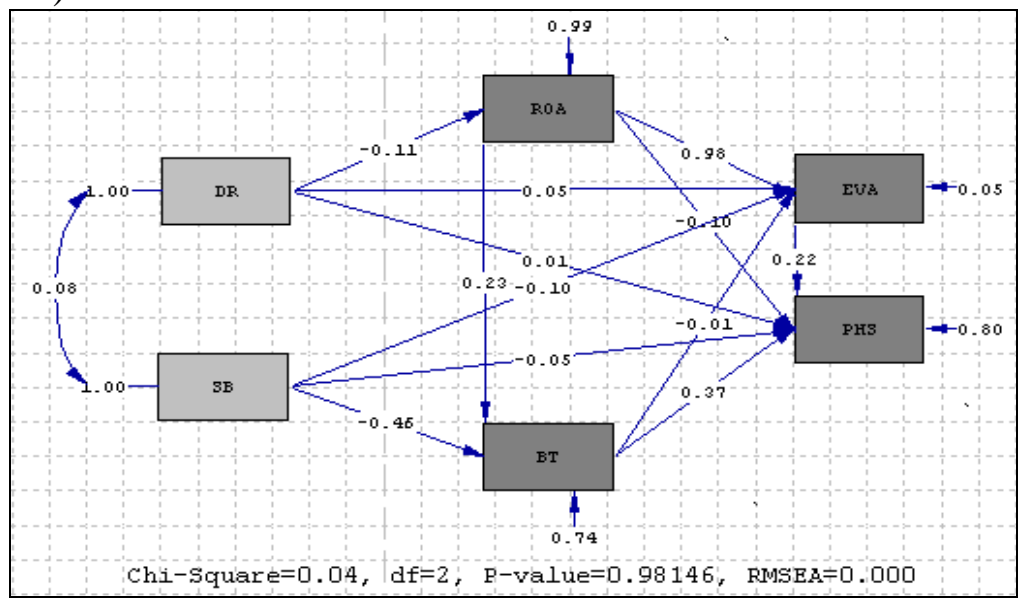

Gambar 1.

Model Analisis Pengaruh FD-EVA-PHS Perusahaan Properti di BEI

\section{Pengaruh Faktor Determinan terhadap EVA dan PHS}

Pengaruh faktor-faktor determinan terhadap EVA berdasarkan model sebagaimana ditunjukkan pada Tabel 3. ROA mempunyai pengaruh terbesar terhadap EVA dengan pengaruh total sebesar 0.978, kemudian suku bunga (-0.099), kemudian debt ratio (-0.057) dan paling kecil adalah beta saham (-0.011). ROA berpengaruh positif, sedangkan suku bunga, debt ratio dan beta saham masing-masing berpengaruh negatif.

Tabel 3.

Dekomposisi Korelasi Faktor Determinan - EVA

\begin{tabular}{|l|r|r|r|r|r||}
\hline \hline Variabel & Direct Effect & Indirect Effect & Total Effect & \multicolumn{1}{|c|}{ U/S } & \multicolumn{1}{|c|}{ Correlation to EVA } \\
\hline DR & 0.051 & -0.107 & -0.057 & -0.008 & -0.065 \\
\hline SB & -0.104 & 0.005 & -0.099 & 0.012 & -0.087 \\
\hline ROA & 0.980 & -0.003 & 0.978 & $-0.006^{\wedge}$ & 0.971 \\
\hline BT & -0.011 & - & -0.011 & $\mathbf{0 . 2 6 5}$ & 0.254 \\
\hline \hline
\end{tabular}

Catatan: *Un-analysed atau Spurious; ^ $\wedge$ Spurious effect.

Tabel 3 juga menunjukkan bahwa bagian tak-teranalisis dari faktor DR dan SB relatif kecil, sehingga mampu mengoptimalkan pengaruh DR dan SB dengan mereduksi bagian tak-teranalisis dari korelasi keduanya terhadap EVA. Selain itu adanya komponen spurious effect pada ROA dan BT menunjukkan bahwa: 
i. Faktor ROA mampu menjadi variabel perantara yang mereduksi pengaruh bersama faktor SB dan DR terhadap EVA. Angka spurious effect dari ROA adalah -0.006, kecil tapi telah mampu mengoreksi pengaruh suku bunga dan debt ratio terhadap EVA.

ii. Faktor BT terlihat sangat berperan sebagai variabel perantara (nilai spurious besar, 0.265) yang mentransmisikan pengaruh SB, DR, ROA terhadap EVA. Dengan demikian, meskipun korelasi BT dengan EVA besar, pengaruh BT sendiri terhadap EVA ternyata kecil sekali (-0.01) karena sebagian besar merupakan pengaruh bersama tiga faktor determinan lainya terhadap EVA.

Pengaruh faktor-faktor determinan terhadap PHS sebagaimana ditunjukkan pada Tabel 4. Beta saham mempunyai pengaruh terbesar terhadap PHS dengan pengaruh total sebesar 0.37, kemudian suku bunga (-0.25), kemudian ROA (0.20) dan paling kecil adalah debt ratio (0.002). BT dan ROA berpengaruh positif, suku bunga berpengaruh negatif, sedangkan debt ratio balances.

Tabel 4.

Dekomposisi Korelasi Faktor Determinan - PHS

\begin{tabular}{||l|r|r|r|r|r||}
\hline \hline Variabel & Direct Effect & Indirect Effect & Total Effect & \multicolumn{1}{c|}{ U/S } & Correlation to PHS \\
\hline DR & 0.012 & -0.010 & 0.002 & -0.022 & -0.020 \\
\hline SB & -0.052 & -0.194 & -0.246 & 0.004 & -0.242 \\
\hline ROA & -0.103 & 0.298 & 0.195 & $-0.005^{\wedge}$ & 0.191 \\
\hline BT & 0.374 & -0.002 & 0.371 & $\mathbf{0 . 0 5 7}$ & 0.429 \\
\hline EVA & 0.217 & - & 0.217 & $-0.001^{\wedge}$ & 0.216 \\
\hline
\end{tabular}

Catatan: *Un-analysed atau Spurious; ^ Spurious effect.

Dekomposisi korelasi pada Tabel 4 menunjukkan bahwa korelasi setiap faktor dengan PHS telah didekomposisi dengan baik. Analisis terhadap bagian spurious effect menunjukkan bahwa:

i. Faktor ROA mampu menjadi variabel antara yang mereduksi pengaruh bersama faktor SB dan DR terhadap PHS. Angka spurious effect dari ROA adalah -0.005.

ii. Faktor BT kembali terlihat sangat berperan sebagai variabel perantara (spurious $=0.057$ ) yang mentransmisikan pengaruh bersama tiga faktor determinan (SB, DR, ROA) terhadap PHS. Artinya bahwa, selain pengaruh langsung, pengaruh suatu faktor determinan terhadap PHS bergantung juga kepada korelasinya dengan beta saham. Karena pengaruh beta saham dengan PHS positif, maka semakin besar korelasi suatu faktor determinan dengan beta saham akan semakin besar juga pengaruhnya terhadap PHS.

iii. EVA sebagai variabel perantara (spurious = -0.001) menunjukkan bahwa peranan EVA kecil dalam menghantarkan pengaruh umum empat faktor determinan terhadap PHS. Meskipun demikian, secara empiris mediasi EVA mampu mengoptimalkan total effect ROA dan SB terhadap PHS, serta mereduksi pengaruh umum DR terhadap PHS. Dekomposisi korelasi EVA-PHS praktis hanya menunjukkan bahwa sebagain besar korelasinya merupakan pengaruh langsung EVA terhadap PHS.

Struktur pengaruh empat faktor determinan terhadap EVA dan implikasinya terhadap PHS dirangkum pada Tabel 5. 
Tabel 5.

Struktur Pengaruh Faktor Determinan terhadap EVA dan PHS

\begin{tabular}{|c|c|c|c|c|}
\hline \multirow{2}{*}{$\begin{array}{c}E V A \\
\text { (total variance } 95 \%)\end{array}$} & \multicolumn{4}{|c|}{ PHS (total variance 20\%) } \\
\cline { 2 - 5 }$(1)[0.37]$ & $(2)[-0.25]$ & $(3)[0.20]$ & $(4)[0.002]$ \\
\hline$(1)[0.98]$ &. & & ROA & \\
\hline$(2)[-0.10]$ & & SB & & DR \\
\hline$(3)[-0.06]$ & & &. &. \\
\hline$(4)[-0.01]$ & BT & & & \\
\hline
\end{tabular}

Catatan: (.) urutan pengaruh; [.] total effect; Sumber : Tabel 3 dan Tabel 4.

Pertama, ROA paling dominan berpengaruh terhadap EVA berimplikasi mempengaruhi PHS dengan arah yang sama tetapi dengan besar pengaruh yang kirakira empat kali lebih kecil. Sehingga ada pergerseran dari pengaruh sangat dominan (urutan pertama terhadap EVA) menjadi pengaruh kedua pada PHS (setelah beta saham). Secara umum, kenaikan satu unit dalam ROA akan menyebabkan kenaikan dalam EVA sebesar 0.98 unit dan selanjutnya berdampak pada kenaikan harga saham sebesar 0.20 unit, ceteris paribus. Jadi, perubahan dalam ROA akan sangat besar dampaknya dalam EVA, sehingga juga akan berdampak terhadap perubahan dalam pergerakan harga saham. Pengaruh ROA terhadap EVA maupun terhadap pergerakan harga saham sesuai dengan skenario model EVA

Kedua, Suku Bunga juga berpengaruh terhadap EVA dengan pengaruh yang cukup besar, berimplikasi mempengaruhi PHS dengan arah yang sama dan dengan besar pengaruh yang kira-kira dua kali lebih besar. Posisi relatif pengaruhnya dibanding faktoe determinan lainnya konsisten baik terhadap EVA maupun PHS. Sesuai dengan skenario model EVA, suku bunga mempunyai pengaruh negatif terhadap EVA maupun terhadap PHS. Secara umum, jika SB naik satu unit, maka EVA turun 0.10 unit, dan akhirnya PHS juga turun sebesar 0.25 unit, ceteris paribus. Jadi, dampak perubahan suku bunga lebih besar terjadi pada pergerakan harga saham daripada EVA.

Ketiga, Debt Ratio berpengaruh terhadap EVA tetapi dengan pengaruh yang tidak begitu besar sehingga tidak berimplikasi mempengaruhi PHS. Secara umum, jika debt ratio naik satu unit, maka EVA turun 0.06 unit, tidak menyebabkan perubahan dalam PHS; ceteris paribus. Jadi perubahan dalam struktur modal hanya berdampak kecil pada perubahan dalam EVA, sehingga tidak berimplikasi terhadap perubahan dalam pergerakan harga saham. Pengaruh debt ratio sesuai dengan skenario model EVA, tetapi karena pengaruhnya kecil terhadap EVA, maka pengaruhnya terhadap pergerakan harga saham tidak signifikan.

Dan, keempat, Beta Saham tidak berpengaruh terhadap EVA sehingga juga tidak berimplikasi mempengaruhi PHS (hal ini terlihat dari pengaruh tidak langsung BT terhadap PHS pada Tabel 4). Akan tetapi, karena BT mempunyai pengaruh langsung yang sangat besar terhadap PHS, maka pengaruh total BT menjadi tetap besar bahkan relatif paling besar dibandingkan pengaruh faktor lainnya. Secara umum, pada perusahaan sektor propeti di BEI, jika terjadi kenaikan beta saham satu unit tidak menyebabkan perubahan dalam EVA, tetapi menyebabkan kenaikan pada pergerakan harga saham sebesar 0.37 unit, ceteris paribus.

Sebagaimana dasar teoritis bahwa model hubungan beta saham dengan pergerakan harga saham tergantung dari: (i) keputusan investor dalam membentuk portofolio, (ii) scenario model EVA, dan (iii) scenario model dividen discount factor (DDF) melalui penilaian harga wajar. Apabila disesuaikan dengan data Tabel 4, maka scenario model EVA maupun DDF menujukkan pengaruh tidak langsung beta saham (-0.002), scenario ini sesuai tetapi besar pengaruhnya tidak signifikan (kecil sekali). 
Pengaruh langsung beta saham dengan pergerakan harga saham merupakan cermin keputusan/strategi investor dalam membentuk portofolionya. Dalam kasus saham sector property di BEI, sebagian besar investor lebih memilih saham dengan beta tinggi, sehingga kecenderungannya adalah harga saham dengan beta tinggi tersebut naik karena permintaan naik. Jadi, secara empiris, beta saham sector property berpengaruh positif terhadap pergerakan harga saham.

\section{Model Tunggal Pengaruh EVA terhadap Pergerakan Harga Saham}

Dalam model bersama dengan faktor-faktor determinan, pengaruh EVA tidak signifikan terhadap PHS. Jika kita analisis pengaruh tunggal EVA terhadap PHS, hasil estimasi model menunjukkan bahwa, EVA mempengaruhi pergerakan harga saham dengan persamaan regresi tunggal (standardized): PHS $=0.216 \mathrm{EVA},(r=0.216, p$ value $=0.026, \mathrm{R}^{2}=4.7 \%$ ). EVA menyumbang sebesar $4.71 \%$ terhadap variasi pergerakan harga saham, menunjukkan bahwa EVA perusahaan sektor properti tahun 2000 sampai dengan 2004 tidak cukup kuat mempengaruhi rata-rata pergerakan harga sahamnya. Secara statistik pengaruhnya koefisien regresi signifikan pada $\alpha=5 \%$. Nampaknya bahwa koefisien regresi tidak berubah antara model tunggal dengan model bersama, tetapi berbeda dalam hal signifikansinya.

\section{KESIMPULAN DAN SARAN}

\section{Kesimpulan}

Pengaruh empat faktor determinan terhadap EVA perusahaan sektor properti di BEI dari yang paling dominan adalah tingkat profitabilitas ROA, suku bunga, struktur modal, dan beta saham. Profitabilitas (ROA) berpengaruh positif, suku bunga, dan dan berpengaruh negatif, pengaruh beta saham tidak signifikan. Sedangkan terhadap pergerakan harga saham, dari yang paling dominan, adalah beta saham, suku bunga, profitabilitas ROA, dan struktur modal. Beta saham dan ROA berpengaruh positif, suku bunga berpengaruh negatif, pengaruh struktur modal tidak signifikan. Pergerakan harga saham perusahaan sektor properti di BEI dipengaruhi oleh EVA meskipun dengan variasi hanya sekitar $4.7 \%$. Jika tingkat EVA naik satu unit-standar, ceteris paribus, maka rata-rata pergerakan harga saham naik 0.22 unit-standar.

Kenaikan satu unit (standar) dalam tingkat suku bunga, ceteris paribus, berdampak pada penurunan EVA 0.1 unit dan pergerakan harga saham 0.25 unit. Kenaikan satu unit debt ratio, ceteris paribus, akan berdampak pada penurunan EVA 0.06 unit, dan tidak menyebabkan perubahan dalam pergerakan harga saham. Kenaikan satu unit dalam ROA, ceteris paribus, berdampak pada kenaikan EVA 0.98 unit dan pergerakan harga saham 0.20 unit. Kenaikan satu unit dalam beta saham, ceteris paribus, tidak menyebabkan perubahan pada EVA, tetapi berdampak pada kenaikan pergerakan harga saham sebesar 0.37 unit.

Pengaruh tiga faktor determinan ROA, struktur modal, dan suku bunga terhadap EVA maupun pergerakan harga saham tergantung korelasi masing-masing faktor tersebut dengan beta saham. Semakin besar korelasinya semakin besar pengaruhnya baik terhadap EVA maupun pergerakan harga saham. Dalam hal ini faktor beta saham efektif berperan sebagai faktor perantara (intervening variable).

\section{Saran}

Disarankan untuk memperluas penelitian serupa pada saham-saham seluruh sektor dengan periode pengamatan yang lebih lama, serta metodelogi yang lebih diperbaiki. Bagi pelaku bisnis (manajemen dan investor), disarankan untuk memantau kinerja ROA dan Beta saham dalam kondisi ekonomi pada tingkat suku bunga tertentu. Termasuk dalam hal publikasi dan diseminasi informasi laporan keuangan dan kinerja saham kepada publik. Hal ini penting karena tingkat ROA, beta saham 
dan korelasi keduanya merupakan indikator bagi kinerja EVA dan pergerakan harga saham. Bagi pihak manajemen, strategi peningkatan kinerja pergerakan harga saham dapat dilakukan baik melalui manajemen EVA maupun dengan intervensi dalam faktor-faktornya, yaitu beta saham, suku bunga, ROA dan debt ratio.

\section{DAFTAR PUSTAKA}

Afriyeni, A., \& Marlius, D. (2017). Analisis Pengaruh Harga Saham Perdana Terhadap Abnormal Return Yang Diterima Investor Studi Pada Bursa Efek Indonesia. https://doi.org/10.31219/osf.io/8z7hx

Afriyeni, A., \& Marlius, D. (2018). Analisis Pengaruh Informasi Prospektus Perusahaan Terhadap Initial Return Saham Pada Pasar Perdana Di Bursa Efek Indonesia. https://doi.org/10.31219/osf.io/kt6c4

Afriyeni, A., \& Marlius, D. (2019). Analisis Faktor-Faktor Yang Berpengaruh Terhadap Ketepatan Waktu Penyampaian Laporan Keuangan Pada Perusahaan Yang Listing Di Bursa Efek Indonesia. https://doi.org/10.31219/osf.io/rv4qf

Afriyeni, A., \& Marlius, D. (2019). Analisis Tingkat Pengembalian Dan Risiko Investasi (Studi Pada Industri Manufaktur Yang Terdaftar Di Bursa Efek Indonesia). https://doi.org/10.31219/osf.io/cfb92

Bodie, Z., Kane, A., and Marcus, A. J. 2002. Investment. McGraw-Hill: New York.

Bollen, K. A. 1989. Structural Equations with Latent Variabels. John Wiley \& Sons: New York.

Garson, G. D. 2000. Structural Equation Modelling. North Carolina State University. http://www2.chass.ncsu.edu/garson/pa765/struktur.htm [10 Juli 2003]

Joreskog, K. G. \& D. Sorbom. 1996. Lisrel 8: User's Reference Guide. Scientific Software International: Chicago.

Myers, R. H., and Milton, J. S. 1991. A First Course in the Theory of Linear Statistical Models. PWS-Kent: Boston.

Pancawati Hardiningsih, L. Suryanto, Anis Chariri. 2002. "Pengaruh Faktor Fundamental dan Risiko Ekonomi terhadap Return Saham pada Perusahaan di Bursa Efek Indonesia: Studi Kasus Basic Industry \& Chemical”, Jurnal Bisnis Strategi. Vol. 8. hal. 83-98. UNDIP: Semarang.

Pedhazur, Elazar J. 1982. Multiple Regression in Behavioral Research: Explanation and Prediction. $2^{\text {nd }}$ ed. CBS College Publishing. Holt, Rinehart and Winston : New York.

Putri, A. D., \& Mayliza, R. (2019). Pengaruh Good Corporate Governance Dan Leverage Terhadap Kinerja Keuangan Pada Perbankan Yang Terdaftar Di BEI. https://doi.org/10.31219/osf.io/b8he7

Ross, S.A., Westerfield, R.W., and Jaffe, J. 2002. Corporate Finance. $6^{\text {th }}$ ed. McGraw-Hill: New York. 
Ryan, Thomas P. 1997. Modern Regression Methods. John Wiley \& Sons: New York.

Scott, D. F., Martin, J. D., Petty, J. W. and Keown. 1999. Basic Financial Management. $8^{\text {th }}$ ed. Prentice Hall: New Jersey.

Sharma, S. 1996. Applied Multivariate Techniques. John Wiley \& Sons: New York.

Stern, J. M., Shiley, J. S., and Ross, I. 2001. The EVA Challenge: Implementing Value Added Change in an Organization. John Willey \& Sons: New York.

Suad Husnan, 1994. Dasar-Dasar Teori Portofolio dan Analisis Sekuritas. Edisi kedua. UPP AMP YKPN: Yogyakarta.

Young, S. D., and O'Byrne, S. F. 2001. EVA \& Manajemen Berdasarkan Nilai. Salemba Empat: Indonesia. 